\title{
Trichomoniasis - are we giving the deserved attention to the most common non-viral sexually transmitted disease worldwide?
}

\author{
Camila Braz Menezes, Amanda Piccoli Frasson, Tiana Tasca* \\ Laboratório de Pesquisa em Parasitologia, Faculdade de Farmácia, Universidade Federal do Rio Grande do Sul. Porto Alegre, Rio \\ Grande do Sul, Brazil. \\ * Corresponding Author: \\ Tiana Tasca, Avenida Ipiranga, 2752. 90610-000. Porto Alegre, Rio Grande do Sul, Brazil; Tel: +555133085325; Fax: +555133085437; \\ Email: tiana.tasca@ufrgs.br
}

\begin{abstract}
Etiology: Trichomonas vaginalis is the etiologic agent of trichomoniasis, the most common non-viral sexually transmitted disease (STD) in the world. Transmission: Trichomoniasis is transmitted by sexual intercourse and transmission via fomites is rare. Epidemiology, incidence and prevalence: The WHO estimates an incidence of $\mathbf{2 7 6}$ million new cases each year and prevalence of $\mathbf{1 8 7}$ million of infected individuals. However, the infection is not notifiable. Pathology/Symptomatology: The $T$. vaginalis infection results in a variety of clinical manifestations - in most cases the patients are asymptomatic, but some may develop signs typically associated to the disease. Importantly, the main issue concerning trichomoniasis is its relationship with serious health consequences such as cancer, adverse pregnancy outcomes, infertility, and HIV acquisition. Molecular mechanisms of infection: To achieve success in parasitism trichomonads develop a complex process against the host cells that includes dependent- and independent-contact mechanisms. This multifactorial pathogenesis includes molecules such as soluble factors, secreted proteinases, adhesins, lipophosphoglycan that culminate in cytoadherence and cytotoxicity against the host cells. Treatment and curability: The treatment with metronidazole or tinidazole is recommended; however, cure failures remain problematic due to noncompliance, reinfection and/or lack of treatment of sexual partners, inaccurate diagnosis, or drug resistance. Therefore, new therapeutic alternatives are urgently needed. Protection: Strategies for protection including sexual behavior, condom usage, and therapy have not contributed to the decrease on disease prevalence, pointing to the need for innovative approaches. Vaccine development has been hampered by the lack of long-lasting humoral immunity associated to the absence of good animal models.
\end{abstract}

doi: $10.15698 / \operatorname{mic} 2016.09 .526$

Received originally: 30.09 .2015

in revised form: 08.01.2016,

Accepted 18.01.2016,

Published 27.06.2016.

Keywords: Trichomonas vaginalis, trichomoniasis, sexually transmitted disease, pathogenicity, MTZ.
Abbreviations:
BspA-Bacteroides surface protein A, $C D C$ - Centers for Disease Control and Prevention,
$\mathrm{CP}$-cysteine proteases,
LPG - lipophosphoglycan,
MIF-macrophage migration inhibitory factor,
MTZ-metronidazole,
NAATs - nucleic acid amplification
tests,
PFP - pore forming protein,
SALIP - saposin-like protein,
STD - sexually transmitted disease,
$T N Z$ - tinidazole,
$T V V-T$. vaginalis virus,
VEC-vaginal epithelial cell.

\section{INTRODUCTION}

The flagellate parasitic protozoan Trichomonas vaginalis was firstly described by Alfred François Donné in 1836 from a vaginal discharge. Although the infection has been considered as mild and curable sexually transmitted disease (STD), the high incidence/prevalence and increasing resistance to the treatment, as well as the association with health complications have raised concern to this disease [1]. The diagnostic still presents failures, since the most used method worldwide, the wet mount examination, has low sensitivity. In addition, the report of positive cases for trichomoniasis is not mandatory and there is no vigilance system to detect the increasing antimicrobial resistance [2, 3]. To aggravate the scenario, there is no alternative treatment to the current Food and Drug Administration (FDA) approved drugs, the nitroimidazoles metronidazole (MTZ) and tinidazole (TNZ) [4]. To achieve success in parasitism, the trichomonads pathogenesis against host cells is 
a complex process that includes dependent- and independent-contact mechanisms. Moreover, T. vaginalis is amitochondriate and presents a large genome with 176 Mbp distributed into six chromosomes, distinguishing features that make it a valuable cellular and molecular model [5].

Overall, excellent papers [6-16] have been published in the last 20 years to highlight the importance of $T$. vaginalis infection to human medicine. This article contributes to claim the attention of public health policies to control this STD.

\section{TRICHOMONAS VAGINALIS AND TRICHOMONIASIS: ETIOLOGY, TRANSMISSION, AND DIAGNOSTIC CONSID- ERATIONS}

The parasite $T$. vaginalis is the etiologic agent of trichomoniasis. The infection occurs in the female and male urogenital tract and humans are the only natural host for the parasite [15]. The parasite exhibits a piriform or round shape, with four anterior flagella and a well developed undulating membrane that are responsible for the characteristic motility essential for direct diagnosis [6]. T. vaginalis presents only the trophozoite stage, although, under stressful conditions, pseudocysts or endoflagellar forms have been described [17]. The role of these resistant forms in the trichomonads life cycle is still not understood. In addition to its unique features, $T$. vaginalis presents hydrogenosomes instead of mitochondria, organelles that are involved in the metabolism adaptation to the hostile infection environment, including specific pathways of cell death [18-20].

The pathogen $T$. vaginalis is transmitted by sexual intercourse and the evidences that corroborate for the classification of trichomoniasis as STD are: (1) high frequency of infection in urethra and/or prostate of male partners of infected women; (2) the prevalence of infection is higher among female attending in STD clinics and among prostitutes than in postmenopausal women and virgins; and (3) the flagellates die outside of the human body, unless they are protected from desiccation [6]. Studies that found $T$. vaginalis among young children contribute to maintain a high index of suspicion for sexual abuse [21, 22]. Although thought to be rare, the nonsexual transmission via fomites and possibly water has been described [23]. The pathogen has also been isolated from the respiratory tract of infants $[24]$ and adults $[25,26]$. Undoubtedly, while producing a nuisance infection, $T$. vaginalis must be considered a clinical pathogen rather than commensal organism.

The trichomoniasis diagnosis must be laboratorial as the symptomatology could lead to confusion with other STDs. Accurate diagnostic procedures are essential to confirm trichomoniasis and direct to the appropriate treatment contributing to control the infection propagation [1]. The most used method for diagnosis is the microscopic examination of wet mounts, which establishes the diagnosis by detecting actively motile organisms [4]. Although this is the most practical and rapid method of diagnosis (allowing immediate treatment), it is relatively insensitive. Immunodiagnostic such as direct immunofluorescent anti- body staining is more sensitive than wet mounts, but technically more complex [4]. Serological ELISA has been reported to present higher sensitivity than microscopy with detection of trichomoniasis in asymptomatic population [27].

Two very sensitive tests approved by the FDA to detect T. vaginalis in vaginal secretions include the OSOM Trichomonas Rapid Test (Sekisui Diagnostics, Framingham, MA), an antigen-detection test using immunochromatographic capillary flow dipstick technology that can be performed at the point of care. The sensitivity and specificity for OSOM Test are $82 \%-95 \%$ and $97 \%-100 \%$, respectively [28]. The other test is the Affirm VP III (Becton Dickinson, Sparks, MD), a DNA hybridization probe test that evaluates for T. vaginalis, Gardnerella vaginalis, and Candida albicans, with sensitivity and specificity of $63 \%$ and $99.9 \%$, respectively [29]. Although very efficient, both tests are not cleared for use with specimens obtained from men [4].

As now updated by the STDs Treatment Guidelines from The Centers for Disease Control and Prevention (CDC, US) [4] the culture of the parasite is no longer considered the gold standard for diagnosing $T$. vaginalis infection once effective molecular detection methods are available. Culture has a sensitivity of $75 \%-96 \%$ and a specificity of up to $100 \%$, but results are not available for 3 to 7 days. In women, examination should be performed on vaginal secretions. In men, anterior urethral or prostatic secretions should be examined, although urine can also be screened for $T$. vaginalis in both sexes and under nucleic acid amplification tests (NAATs). The APTIMA T. vaginalis assay (Hologic GenProbe, San Diego, CA) detects RNA by transcriptionmediated amplification from vaginal, endocervical, or urine specimens from women with a clinical sensitivity of $95.3 \%$ $100 \%$ and specificity of $95.2 \%-100 \%$ [30].

In general, both guidelines from East European countries [31] and from CDC [4] recommend the following procedures for the laboratory diagnosis of trichomoniasis: (i) to perform diagnostic testing in all women with vaginal discharge, especially in high prevalence settings (e.g., STD clinics) and for asymptomatic persons at high risk for infection (e.g., persons with multiple sex partners, exchanging sex for payment, illicit drug use, or a history of STD); (ii) to employ NAATs or culture if no trichomonads are detected on microscopic examination of the wet mount preparation and there is a strong indication of infection. It is our understanding that highly sensitive (e.g., NAATs or culture) tests are not feasible in most laboratories especially from developing countries. In such cases, the wet mount examination of vaginal and urethral secretions and the urine sediment with careful specimen preservation and immediate microscopic examination can improve diagnostic sensitivity. Although $T$. vaginalis may be an incidental finding on a Papanicolaou test, neither conventional nor liquid-based Pap tests are considered diagnostic tests for trichomoniasis, because false negatives and false positives can occur [4]. In addition, stained smears by Giemsa or Leishman at clinical settings are being discouraged [31]. 


\section{TRICHOMONIASIS IN NUMBERS}

Trichomoniasis is the most common non-viral STD in the world. The WHO estimative performed in 2008 shows an incidence of 276 million new cases each year and a prevalence of 187 million of infected individuals with ages between 15 and 49 years-old [2]. The incidence of infection depends on several factors including age, sexual activity, number of sexual partners, other STDs, menstrual phase, diagnosis techniques, social, and economic conditions. The prevalence is high among low social income patients from gynecologic and STDs clinics. The flagellates do not survive outside the human body unless they are protected from drying. Live $T$. vaginalis has been found in urine and in semen after several hours of exposure to air [6].

The worldwide prevalence of trichomoniasis is much higher than other curable STDs such as gonorrhea and syphilis, both counting for 36.4 million cases, and Chlamydia infection, with 100.4 million of infected adults. In the USA, several studies have determined the trichomoniasis prevalence in the range of $2.5 \%$ to $26.2 \%$ [32-40]. Considering the Asian continent, consistent survey reports revealed prevalence values of $7.8 \%$ in South Korea [41] and $8.5 \%$ in India [42]. Trichomoniasis prevalence varied from $8.4 \%$ to $48 \%$ among Indigenous patients in Australia [43, 44]. The Nordic countries in Europe account with $1.5 \%$ for the trichomoniasis prevalence [45] and in South Africa the prevalence was $6.5 \%$, excluding co-infection cases with HIV [46]. Studies in Latin America revealed similar prevalence values of $7.6 \%$ in Argentina [47] 7.8\% in Chile [48] and 9.1\% in Peru [49]. In Brazil, prevalence ranged from $2.6 \%$ to $20 \%$ among women [50-53] and the Health Ministry estimates a general prevalence of $15 \%$ [54]. These uncertain data are due to the limitations in sample selection, since it is not representative of the Brazilian population in general.

In this context, Secor et al. [1] alert to the classification of trichomoniasis as neglected disease since the prevalence data are underestimated due to failures in diagnosis as consequence of insensitive methods or lack of testing in asymptomatic patients, and limited knowledge related to infection duration [55]. Moreover, trichomoniasis is not notifiable, and there is no vigilance system to detect drug resistance, with low attention in the public health programs for STDs control [2, 3]. As a consequence of this overlooking, high costs and healthcare burden associated to trichomoniasis account to $\$ 24$ million per year in the United States [56]. The health complications caused by $T$. vaginalis aggravate the situation, as unrecognized costs with pregnancy adverse outcomes, infertility, cervical and prostate cancers are of concern. The estimated cost of the $T$. vaginalis-attributable HIV infections is approximately \$167 million per year [57].

\section{THE TRICHOMONIASIS CLINICAL SPECTRUM AND \\ HEALTH CONSEQUENCES}

The $T$. vaginalis infection results in a variety of clinical manifestations - in most cases the patients are asymptomatic, but some may develop signs typically associated to the disease. Moreover, beyond the symptoms, the main issue concerning trichomoniasis is its relationship with serious health consequences such as cancer [58-60], adverse pregnancy outcomes [61-64], infertility $[65,66]$, and HIV transmission and acquisition $[67,68]$.

Studies have shown a wide divergence in the statistics on symptomatology of trichomoniasis. A couple of years ago, the infection was traditionally known as symptomatic in women and asymptomatic in men. The data of symptomatic women ranged between $50-75 \%[6,7,69]$ while in men the percentage was $15-50 \%[7,70]$. Currently the scenario is changing and recent data have mentioned that around $80 \%$ of $T$. vaginalis infections are asymptomatic in both men and women [16, 32, 71].

The preferential cells infected by the parasite are those of squamous epithelium. In women, the major infection site is the vagina but urethra and endocervix are also reached by the trophozoites $[7,69,72]$. The normal vaginal $\mathrm{pH}$ is 4.5 and it is increased to 5 or more in presence of $T$. vaginalis. This enhancing of $\mathrm{pH}$ promotes the reduction of Lactobacillus acidophilus presence - the healthy microbiota which protects the vaginal epithelium - and consequently, contributes to the multiplication of anaerobic bacteria responsible for the bacterial vaginosis $[6,12]$. This disturbance of genital tract site does not necessarily lead to a symptomatic condition. Although most of the literature establishes the incubation period of trichomoniasis as 4 to 28 days, this period is not clearly known yet [73], and one third of women become symptomatic within 6 months [6].

Among the symptomatic women, the main complaints are vaginal discharge, pruritus, odor, and irritation [72]. The vaginal discharge is a classical signal of trichomoniasis and it is due to intense leukocytic infiltration within the genital tract as a result of the death of epithelial cells which promotes inflammation and leads to an increased number of polymorphonuclear leukocytes in vaginal fluid [74]. The typical discharge is recognized as frothy and yellow/green; however, the aspect and consistency of it may be widely variable among the patients $[70,73]$. Moreover, the vagina and cervix of women with trichomoniasis may be erythematous and edematous, and when punctuate hemorrhagic spots are found on the mucosa this condition is known as colpitis macularis or "strawberry cervix". This clinical sign is the most specific indicative of trichomoniasis although it is clinically diagnosed only in $2-5 \%$ of women [7]. Some patients have still reported dysuria and lower abdominal pain. It is important to highlight that the infection symptoms are cyclic and more intense around the menses period because of the effect of iron on parasite pathogenesis [6]. These clinical features may be associated with vaginitis, cervicitis and other complications. Endometritis, adnexitis, pyosalpinx, and atypical pelvic inflammatory disease are all disorders of the female genital tract related to $T$. vaginalis infection $[55,75]$. Importantly, trichomoniasis may also impact on the pregnancy course, causing low birth weight, premature rupture of membranes and preterm delivery [64]. There are some evidence that $T$. vaginalis infection can be transmitted vertically leading to cases of vaginal and respiratory infections in neonates; fortunately, the clinical improvement in these patients was 
reported after MTZ treatment or even with only supportive care [24]. Another important issue regarding complications of trichomoniasis in women is its involvement with an increased risk of cervical cancer. Some studies have pointed T. vaginalis as a predictor for cervical neoplasia since there is a high relative risk of preinvasive lesion and invasive cancer in patients with trichomoniasis [60]. A meta-analysis found that the parasite was associated with a 1.9-fold risk of this cancer [58].

The spectrum of trichomoniasis in men is less well characterized than in women once the infection is commonly self-limited and transient $[12,73]$. These characteristics may be associated to the oxidative nature of male genital fluid that is hypothesized to be inhibitory to certain pathogenic factors as well as to the zinc concentration in prostatic fluid which acts as cytotoxic factor [66]. However, T. vaginalis is a recognized cause of urethritis accompanied by scanty, clear to mucopurulent discharge, dysuria, and mild pruritus or burning sensation immediately after sexual intercourse [6]. Other complications include prostatitis, balanoposthitis, epididymo-orchitis, and possibly infertility. There is not a consensus on the relationship between trichomoniasis and fertility, but in recent studies the parasite has been considered a contributing factor to male subfertility or infertility. As possible mechanisms involved in this case are the chronic infection, the cell lysis with toxicity to the sperm and the inflammatory process [66]. $T$. vaginalis may be also related to cancer in men. To date, there are few studies investigating the association between the protozoan infection and prostate cancer risk [76-78]. Although conflicting results have been found regarding $T$. vaginalis serostatus and prostate cancer, recent evidences strongly suggest this association [77, 78]. The frequent chronic course of the infection in men turns possible that the parasites ascend to the prostate and establish a site of inflammation that may lead to prostate cancer [79].

Certainly, one remarkable aspect in $T$. vaginalis infection is its positive association with both transmission and acquisition of HIV. The evidences that corroborate to this concern are substantial although still underappreciated [80-82]. Studies have shown that trichomoniasis is associated with as much as a 2.7-fold increase in the risk of HIV acquisition [16]. This data is especially significant taking into account the high prevalence of trichomoniasis within the general population, and in particular within risk groups [7]. Some approaches (e.g., mathematical modeling) have been developed to estimate the number of transmitted HIV infections attributable to $T$. vaginalis, and the high efficacy of these methods are closely related to the need of improving the parasite diagnosis [68]. The main discussed mechanisms by which $T$. vaginalis may enhance HIV acquisition are microhemorrhages in the mucosa caused by the flagellated, inflammatory response of vaginal, exocervix, and urethral epithelia followed by the recruitment of target immune cells, of secretory leukocyte protease inhibitor and association with increased HIV viral load in genital secretions $[68,82]$. Finally, the $T$. vaginalis control, through prevention, diagnosis and treatment, may have a pivotal impact on preventing HIV acquisition and transmission.

\section{PATHOGENICITY - OPENING THE "BLACK BOX" OF TRICHOMONAS VAGINALIS INFECTION}

The $T$. vaginalis infection is very complex with a broad range of symptoms which may be attributed to distinct pathogenic process mediated by the parasite through contact-dependent and -independent mechanisms [8]. The colonization of the infection site is initiated when the parasite triggers cellular damage in the host tissue by secreting a wide variety of molecules, known as cytolytic factors. Trichomonas vaginalis factor (TvF), a $250 \mathrm{kDa}$ cytolytic effector, causes cell rounding and clumping without lysis [83]. Another soluble factor released into the medium by the parasite in contact with cells is a glycoprotein with $200 \mathrm{kDa}$, known as cell-detaching factor (CDF) which promotes cell detachment [84]. In T. vaginalis, high levels of proteolytic activity were attributed to cysteine proteases (CPs), proteins localized in parasite surface, although only a few CPs have been demonstrated and characterized [85]. It has been shown that the parasite could modulate cell recognition and adhesion to the epithelial host cells through the proteolytic activity mediated by T. vaginalis CPs [86]. In addition to the essential role for the colonization in the site of infection, these proteins play an important function in evading host immune defenses, since they degrade IgA and IgG antibodies as well as human extracellular matrix and complement proteins $[87,88]$. The synthesis and proteolytic activity of certain CPs are modulated by environmental factors such as iron, $\mathrm{pH}$, temperature, and polyamines [89].

Red blood cells are a main source of iron and lipids for $T$. vaginalis metabolism and erythrocytes lysis mediated by the parasite have already been demonstrated in vivo. It has already been suggested that haemolytic activity contributes to acquisition of nutrients, mainly iron, and these mechanism may be responsible for the exacerbation of symptoms observed during and following menstruation [90]. Haemolysis is considered a complex process possibly involving several molecules as surface CPs, pore-forming proteins (PFPs), and phospholipase-A-like proteins, which have already been demonstrated as cytolytic factors in $T$. vaginalis [91-95]. Haemolysis involves the regulation of temperature, concentration of $\mathrm{Ca}^{++}$and $\mathrm{pH}$ (as acid environment is required) and the activity of PFPs [96]. These PFPs contribute to cell lysis and death by forming transmembrane channels in the lipid membrane of target cells which leads to osmotic lysis [97].The presence of these PFPs have already been observed in other parasitic protists such as Entamoeba histolytica [98] and Naegleria fowleri [99] known as amebapores and naegleriapores, respectively. These PFPs are members of a conserved family of saposin-like proteins (SAPLIPs) that are found in phylogenetically distant organisms (e.g., protists and mammals). Several functions have been attributed to these proteins, however the interaction with lipids is a common hallmark attributed to this family. Twelve SAPLIP predicted genes (TVSaplip1 and 12) have been identified in T. vaginalis by 
genomic analysis. Based on the characteristics displayed by TvSaplips family, these predicted proteins named trichopores, are good candidates as effectors contributing to the cytolytic effects of $T$. vaginalis. Taking into account the heterogeneous nature of SAPLIP activities, it is not plausible to attribute to all TvSaplips the direct involvement in the cytopathogenicity of this parasite and other biological roles may be involved [100].

Recent studies demonstrated the secretion of exosome-like vesicles by the parasites beyond protein and soluble factors. Genetic studies identified tetraspanins, proteins that are markers of exosomes [101]. T. vaginalis exosomes are about $50-100 \mathrm{~nm}$ in diameter and contain RNA and a variety of proteins. Remarkably, $T$. vaginalis exosomes demonstrated to bind to host cells and modulate parasite virulence against vaginal and prostate cells. Moreover, these vesicles demonstrated to have immunomodulatory properties, enhancing the possible role of the secreted molecules in the establishment of the infection [102].

Also important in modulating parasite-host cell interaction, another factor has been described, the $T$. vaginalis macrophage migration inhibitory factor (TVMIF) which is $47 \%$ similar to human macrophage migration inhibitory factor (HuMIF), a proinflammatory cytokine [103]. It has been shown that TVMIF binds with high affinity to the human CD74 MIF receptor which activates cascades involved in cell proliferation and invasion. The presence of antiTVMIF antibodies indicates that the factor is released by $T$. vaginalis and may result in inflammation and cell proliferation, thus activating pathways that contribute to the promotion and progression of prostate cancer [103].

The multifactorial nature of trichomonal pathogenesis also involves a sequence of events, where contactdependent mechanisms play crucial roles. Upon contact with host cells, the parasite undergoes a drastic morphological shift. The free-swimming piriform trophozoites transform into an ameboid form leading to a tight association to the target cells [8]. Actin proteins participate at this step inducing the cytoskeletal rearrangement and cellular proliferation. In this way, Gould et al. [104] showed the upregulation of actin and actin-associated genes of $T$. vaginalis after contact with vaginal epithelial cells (VECs). While $\alpha$ actinin is distributed throughout the cytoplasm when the cell is pear-shaped, the protein localizes only at the cell periphery when the trophozoites are in the ameboid form. The morphological transition from pear-shaped flagellates to tissue-feeding and actively dividing amoeboid organisms occurs in a few minutes and represents a crucial step of the infection process [10].

The typical mucous layer covering the VECs is part of the non-specific host defenses [105]. The parasite can cross this barrier by binding and degrading mucin - a large glycoprotein with gel-like property that forms a lattice structure and serves as a formidable physical barrier to microbial invasion. T. vaginalis binds to mucin, possibly via lectin-like adhesion, and secretes mucinases able to degrade the protein over a pH range of 4.5-7.0 [106]. Directly related to those processes is cytoadherence - the major event of $T$. vaginalis pathogenesis. The mechanisms of cell adhesion are extensively studied in the parasite and up to now three major classes of molecules show evidence to be involved in the cytoadherence: lipophosphoglycan, adhesins and a collection of membrane proteins that have been recently identified through genomics and proteomics [87].

The $T$. vaginalis lipophosphoglycan (TVLPG) is one of the most abundant components of the glycocalyx - the outer layer of the cell membrane formed by different carbohydrate-associated molecules - that binds to galectin-1 and -3 receptors in the host cells $[107,108]$. TVLPG plays a role in the parasite-host cell interaction to VECS once $T$. vaginalis mutant cells deficient in TVLPG glycosylation showed reduced adherence and cytotoxicity to human cervical cells [109]. This molecule also participates in parasite virulence modulating inflammatory responses of epithelial cells and macrophages [110].

The second class of $T$. vaginalis proteins related to adherence comprises the named adhesins - five proteins (AP120, AP65, AP51, AP33, and AP23) that apart from AP23, are abundant metabolic enzymes primarily involved in carbohydrate metabolism and found in the hydrogenosome [111]. Conversely, it has been already demonstrated that these proteins are also present on parasites surface [112, 113], contributing to the hypothesis of their dual function: metabolic proteins and adhesins [114]. This family of proteins also participates in the molecular mimicry mechanisms involved in immune evasion [8]. Apart from the studies showing the surface localization of the adhesins, it has already been shown that these proteins are exclusively situated in the hydrogenosomes [115] and that they lack some features that are present in true adhesion proteins like transmembrane domains [115]. The precise role of the adhesins in pathogenesis is still uncertain as some studies have already verified the interaction of these proteins with the host cell surface [116, 117] in contrast with authors that demonstrated that $T$. vaginalis binds to cell target in the absence of membrane proteins [118]. In agreement with the hypothesis that attributes a lack of adherence specificity for the adhesins, data demonstrated that AP51 and AP65 bind to haem and haemoglobin, a feature that evidences a function in the nutrient acquisition and metabolism, not related to adhesion properties [119]. More studies, especially on the molecular basis are required in order to support that $T$. vaginalis adhesins acts as dual function proteins, verifying specific binding in cell targets as the recruitment of these proteins to the surface of the parasite.

Some studies have already demonstrated the regulation of adherence levels promoted by environmental regulation in the adhesins synthesis and metabolism. High levels of iron present in a complex supplemented medium lead to increased levels in trophozoites adherence [120] The increase was specially attributed to iron as parasites cultured in a low-iron medium and in the presence of salts other than iron were unresponsive to changes in adherence levels [120]. Additionally, it was demonstrated that the higher adherence levels were a result of increased gene expression of AP65, AP51, AP33, and AP23 adhesins 
[120]. Regarding the localization and compartmentalization of these proteins in T. vaginalis under contact with epithelial cells, it was already verified that high-iron-grown parasites co-expressed adhesins on the surface and intracellularly in contrast with low-iron parasites [121]. More significantly, the study showed that MR100 trichomonads, a drug-resistant isolate lacking hydrogenosome proteins and adhesins, presented non-adherent profile [121]. Besides iron modulation, $T$. vaginalis adhesion under contact with epithelial cells may also be regulated by other environmental mechanisms. When comparing the interaction of $T$. vaginalis adhesins with epithelial cells of fresh clinical and long-term-grown isolates it has been shown that fresh isolates presented greater amounts of adhesins, which corresponded to higher levels of cell adherence [117]. These data suggest that some virulence factors that are still present in fresh clinical isolates may interact and regulate the adhesin metabolism and expression [117].

The last group of molecules speculated to be associated to the parasite adherence are the surface proteins, as BspA (Bacteroides surface protein A)-like. BspA-like are the largest surface protein family identified in $T$. vaginalis with evidence of expression for 721 members [104, 122]. Bacterial BspAs are able of mediating binding to host epithelial cells, extracellular matrix proteins and cell aggregation [8, 122]. Similarly, T. vaginalis BspA-like proteins are strong candidates of surface proteins mediating interaction with various mucosal hallmarks including: mucus, VEC, urethra epithelial cells, and vaginal microbiota [122]. In silico analysis reveals other transmembrane proteins that are possibly involved in the host-parasite interaction, which comprise the GP63-like, subtilisin-like, serine proteases, and calpainlike cysteine proteases [115]. However, although genomic and proteomic analyses have identified these proteins on the parasite surface, none of them have been characterized in detail and their putative role in host-parasite interactions is only hypothesized [10].

Another important factor contributing to $T$. vaginalis pathogenesis is the high cytotoxic potential of the parasite. Its ability to promote cytolysis followed by phagocytosis is what triggers the disruption of cell monolayers [8]. Many are the factors involved in these processes, including contact-independent mechanisms. When attached to the parasite, the host cells may be phagocyted both by a 'sinking' process without any apparent participation of plasma membrane extensions as by the classical phagocytosis where pseudopodia are extended toward the target cell. Dramatic changes in the distribution of fibrillar actin have also been reported, which may facilitate the ameboid morphological transformation observed during phagocytosis [123]. After the internalization of bacteria, yeasts and cells such as VECs, cervical and prostate cells, leucocytes and erythrocytes, the parasite digests the material in lysosomes [124]. Hemolysis is another issue closely related to $T$. vaginalis cytotoxicity since the erythrocyte lysis is one source of important nutrients such as lipids and iron [90]. This process is mainly contact-dependent and surface cysteine proteases, pore-forming proteins and phospholipaseA-like proteins are involved $[93,125]$.
The host defense in response to $T$. vaginalis infection involves multiple mechanisms such as non-immunological factors, non-specific and specific mechanisms of the innate immune response $[55,73]$. Non-immunological factors include the effects of environmental elements such as iron, zinc and polyamines, which directly modulate the expression of virulence genes in the parasite [8]. In this sense, it was already shown that iron mediates $T$. vaginalis resistance to complement lysis due to proteinase degradation of C3 on the trichomonal surface [126].

The immune system of mucous layer is the first line of defense against pathogenic organisms in the urogenital tract and involves both innate and adaptive immune responses, including cellular and humoral immunity. Trichomoniasis does not produce an effective permanent immunity, which may lead to recurrent infection, consequently, innate immunity response has become crucial in the infection control [55]. Upon contact with host cells and binding through $L P G, T$. vaginalis trophozoites trigger an inflammatory response in the VECs through the release of cytokines and chemokines, mainly interleukin-8 (IL-8), interleukin-6 (IL-6) and macrophage inflammatory protein (MIP-3 $\alpha$ ) [55]. IL-8 production and release is also mediated by human neutrophils, major immune cells recruited to the site of inflammation and the predominant inflammatory cells found in the vaginal discharges of patients infected with $T$. vaginalis [127]. Additional innate immune mediator induced by $T$. vaginalis is nitric oxide, which is produced by several cell types such as neutrophils and macrophages. It was already demonstrated that $T$. vaginalis trophozoites in contact with human neutrophils are able to stimulate the release of high levels of nitric oxide through the nitric oxide synthase [128].

Despite the predominance of innate immune responses, adaptive immunity mediated by the production of parasitespecific antibodies may play an important role in the infection control by host cells, since IgA and IgG immunoglobulins are detected in vaginal secretions of symptomatic women [129]. In man, IgG1 and IgM antibodies detected may be involved in the establishment of symptomatic trichomoniasis, compared to asymptomatic cases [130]. However, all antibodies produced and/or secreted during trichomoniasis only promote a limited protection to the parasite gradually declining after the eradication of infection in a period of six to twelve months. After infection, $T$. vaginalis specific antibodies and memory $B$ cells are not found in the circulation, leaving the host without defense mechanisms against a possible reinfection [131]. For this reason, it becomes so complex to establish the presence of antibodies in the diagnosis of trichomoniasis as well as to progress in research for effective vaccines.

Regardless of several innate and adaptive responses triggered by the host cells in order to control the infection, $T$. vaginalis evolved diverse immune evasion mechanisms. The secretion of proteases, specifically $\mathrm{CP}$ which degrades human immunoglobulins, not only keeps the survival of the parasite but also supplies nutritional demands trough hemolytic properties [125]. Another important evasion mechanism comprises molecular mimicry in which parasite 
covers its membrane with molecules homologous to host proteins. The $T$. vaginalis adhesins (AP65, AP51 and AP33) are homologous to host metabolic enzymes and plasma proteins, in attempt to avoid the recognition by the host immune system [8]. The secretion of immunogenic soluble proteins into the infection site by the parasite seems to neutralize circulating antibodies and facilitates the continuous colonization and infection of the vagina [7]. Despite all the immune responses mediated by the host cells, $T$. vaginalis is able to evade those mechanisms and displays the whole pathogenic potential which turns trichomoniasis a chronic and persistent infection.

Finally, $T$. vaginalis may exert a "Trojan horse" role in the microbial environment, since it can have a symbiosis relationship with Mycoplasma hominis, a small bacterium associated with urogenital and respiratory system infections [132]. Studies demonstrated that the association of both microorganisms presents prevalence values greatly ranging from 20 to $92 \%$ [132-135] and it might influence the cytopathogenic effect of $T$. vaginalis on epithelial cells and inflammatory responses [136, 137]. In addition, a strong relationship between $M$. hominis co-infection and MTZ resistance in vitro was shown [135] contrasting to studies that revealed the lack of this correlation [133, 134].

Besides $M$. hominis, $T$. vaginalis can also be infected with four viruses, known as $T$. vaginalis virus (TVVs) that are members of the Totiviridae family [138]. Large variability is found in the prevalence values, from 13 to $90 \%$ of $T$. vaginalis isolates harboring TVVs $[134,139,140]$. The participation of the virus in the virulence of $T$. vaginalis is under investigation. An association between the presence of viruses and expression of immunogenic proteins on the trichomonal surface, variations in protozoan phenotypes, and upregulation of certain virulence factors has been shown [141]. Notably, Fichorova et al. [142] suggest focus in TVVs as targets for new therapeutic paradigms thus preventing the inflammatory sequelae caused by virusharboring parasites.

Efforts have been made to know how $T$. vaginalis succeeds parasitism and infection, and the studies on genomic, proteomic and transcriptomic have brought considerable advances on the information on gene and protein expression that contributes to the comprehension of several biological functions [143]. One of the cornerstones that partially explain the parasite complexity is the extensive gene duplication and presence of multiple gene families in the $T$. vaginalis genome as well as the impressive percentage of $86 \%$ hypothetical proteins $[5,143]$. The publication of the first $T$. vaginalis genome in 2007 resulted in considerable advances in the knowledge of the biology of the parasite and continuous efforts on the "omics" database, TrichDB, are being stimulated to contribute to solve the remaining gaps in the field. Huang et al. [144] constructed a proteome reference map of $T$. vaginalis by using two-dimensional electrophoresis combined with matrix-assisted laser desorption ionization time-of-flight mass spectrometry analysis and found that proteins related to carbohydrate metabolism represented the most abundant category in the $T$. vaginalis trophozoite stage [144]. Following this initial analysis, several recent reports at the transcriptomic level have demonstrated the parasite responses to stress conditions such as glucose and iron restrictions by using next generation RNA sequencing $[145,146]$. Glucose restriction elicits trichomonads antioxidant ability and autophagy to maintain survival trough a metabolic reprogramming. In the same way, nitric oxide exerts a cytoprotective effect on iron-deficient $T$. vaginalis by maintaining the hydrogenosomal membrane potential [146]. Furthermore, the transcription of iron-regulated and iron-independent gene copies was analyzed and multiple gene copies were shown to be advantageous for the parasite to differentially express genes and proteins under stringent regulation in variable environmental conditions [147]. Besides nutrients metabolism, functional analysis showed the effects of cold temperature on cellular pathways including $\mathrm{H}_{2} \mathrm{O}_{2}$ tolerance, activation of the ubiquitin-proteasome system, induction of iron-sulfur cluster assembly, and reduced energy metabolism and enzyme expression [148]. Moreover, considering the crucial pathogenic process of cytoadherence, integrated transcriptomic and proteomic approaches revealed that cysteine peptidase, glyceraldehyde-3phosphate dehydrogenase, and stress-related proteins were upregulated in the fibronectin-adherent parasites, indicating that these genes and proteins may play critical roles in the response to adherence [149]. Another approach to investigate protein expression was the phosphoproteome involved in the morphological alterations from the pear-shape form to ameboid and pseudocysts in $T$. vaginalis, where a total of 93 phosphopeptides originating from 82 unique proteins involved in these processes were found [150]. Next-generation sequencing-based RNA sequencing was also employed to analyze the transcriptome of $T$. vaginalis in response to tetracycline, a broadspectrum antibiotic with activity against several protozoan parasites [151]. Tetracycline was cytotoxic against MTZsensitive and -resistant $T$. vaginalis isolates, inducing some features resembling apoptosis, altering the transcriptome via aminoacyl-tRNA synthetases and carbohydrate metabolism, and causing disruption on the hydrogenosomal membrane potential and antioxidant system. Altogether, these data revealed the potential of tetracycline as alternative therapeutic choice for treating MTZ-resistant $T$. vaginalis [151].

Overall, this intriguing extracellular pathogen establishes infection through coordinated crucial steps: morphological alteration from pear-shaped to ameboid forms followed by cytoadherence and release of virulence factors. This complex mechanism leads to tissue colonization with immune evasion, culminating in a good parasitism success. Although these pathogenic mechanisms have been progressively revealed, the continue efforts to elucidate the "trichomonads black box" are required.

\section{TREATING TRICHOMONIASIS: ARE WE SUCCEEDING?}

Considering the whole spectrum of clinical manifestations and the complications arising from the infection, $T$. vaginalis vaginitis requires prompt and effective treatment. 
Nitroimidazole drug family, mainly represented by MTZ and TNZ, has been used as antitrichomonal agents for more than 30 years, being MTZ the treatment of choice [13]. This class of drugs is the only one approved by the FDA for $T$. vaginalis infection treatment. These medications are widely available in public health systems and quite inexpensive, especially MTZ. TNZ has a longer half-life and reaches a higher genitourinary tract drug level than MTZ, but it is more expensive [9]. Therapeutic approaches used in the treatment of trichomoniasis are local intravaginal applications, systemic oral medication and the association of both. There is also evidence that a spontaneous cure rate in the order of $20-25 \%$ is achieved [152]. As $T$. vaginalis in women frequently infects the urethra and paraurethral glands cure and local medication reaches just around $50 \%$, the oral medication treatment is preferred. A Cochrane review described that in most trials single dose treatment with any nitroimidazole drug leaded in trichomonicidal actions upon $90 \%$. Despite rarely severe, side effects appeared to be relatively common and dose related [152].

According to the 2015 STD Treatment Guidelines from CDC the recommended regimens for treating trichomoniasis correspond to $2 \mathrm{~g} \mathrm{MTZ}$ or TNZ orally in a single dose [4]. MTZ gel is considered less efficacious than oral treatment (fewer than $50 \%$ ) since topical preparations cannot achieve therapeutic levels in the urethra or perivaginal glands. As an alternative regimen, $500 \mathrm{mg}$ oral dosage of MTZ can be used twice a day for 7 days [4]. Distinct recommendation is given by the United Kingdom on the Management of Trichomonas vaginalis 2014, where TNZ $2 \mathrm{~g}$ orally in a single dose is considered an alternative regimen and the recommended regimen is based on the two possible doses of MTZ treatment [153]. In order to compare the efficacy of different regimens of MTZ and TNZ some studies were already conducted. MTZ in two different single doses $(1.5$ or $2.0 \mathrm{~g})$ demonstrated equivalent efficacy for trichomoniasis treatment [154]. The multidose regimen (500 $\mathrm{mg}$ twice a day for 7 days) was more effective than the single dose ( $2 \mathrm{~g}$ orally) for the treatment of trichomoniasis among co-infected HIV-T. vaginalis subjects [155]. It is important to emphasize that this study was the first to evaluate the effectiveness of treatment for trichomoniasis among HIV-infected women. These data suggest that the recommended standard regimen of MTZ may need to be reconsidered for HIVinfected women reinforcing that more studies are necessary to investigate optimal treatment regimens for distinct patient populations presenting co-infecting pathogens. A different approach was evaluated using single-dose intravaginal MTZ (2 g) in comparison to singledose oral MTZ (2 g) which demonstrated that the intravaginal use was inferior to single-dose oral MTZ, failing as an alternative therapy [156]. Several other antimicrobial preparations, mostly used for bacterial vaginosis treatment are also used for $T$. vaginalis infection, although with lower effectiveness than MTZ [4]. The overall cure rates are not significantly different between MTZ and TNZ regimens and no significant differences in adverse events across treatment were obtained [152, 157]. The side effects are also a disadvantage for the treatment with MTZ or TNZ.

In relation to possible side effects during treatment, patients should be recommended not to ingest alcohol for at least 48 to 72 hours due to possible toxicity effects. Referring to allergies, hypersensitivity reactions have been described in patients using both MTZ and TNZ and it is unknown whether there is cross-reactivity between the two agents [152]. Considering that nitroimidazoles are the only therapeutic option available, it is important to take an accurate history to establish that a true allergy exists otherwise standard treatment will be unviable. Furthermore it is not well established if TNZ is well tolerated in a patient with MTZ allergy. Adverse reactions which may occur include anaphylaxis, skin rashes, pustular eruptions, pruritus, flushing, urticaria, and fever [158].

Vaginal trichomoniasis has been associated with adverse pregnancy outcomes, particularly preterm delivery and low birth weight [61]. Multiple studies and meta analyses have not demonstrated an association between MTZ use during pregnancy and teratogenic or mutagenic effects in newborns and infants [159-161]. Symptomatic pregnant women should be treated at diagnosis, although some clinicians prefer to delay treatment to the second trimester. The safety of TNZ in pregnant women, however, has not been well established. In lactating women who are administered MTZ, avoiding breastfeeding during treatment and for $12-24 \mathrm{~h}$ after the last dose will diminish the exposure to MTZ. For women treated with TNZ, interruption of breastfeeding is recommended during treatment and for 3 days after the last dose [152, 162].

The reliance on a single therapeutic class is problematic since resistance to nitroimidazoles is becoming widespread in $T$. vaginalis isolates. There is very limited information on the prevalence of resistance to MTZ among clinical isolates of $T$. vaginalis, especially because no surveillance systems are implemented to detect treatment failures due to resistance and antibiotic susceptibility testing for $T$. vaginalis is not standardized. Studies indicate an increasing prevalence of 2.5 to $9.6 \%$ of MTZ-resistant isolates [3, 163, 164]. Although the low prevalence of nitroimidazoles resistance occurs, more studies focused on this research area are urgent, as only two agents are available for treatment. Recent works are exploring genomic sequences aiming to identify possible target candidate genes in $T$. vaginalis drug resistance based on the role of these sequences in other organisms [143]. It has already been shown that $T$. vaginalis presents homologs of bacterial nitroreductases and nitroimidazole reductases that are lacking in the majority of eukaryotes are related with reduced susceptibility to MTZ in Helicobacter pylori and Bacteroides [165]. It is not still clear if these genes are associated with nitroimidazole sensitivity in the parasite, but it was demonstrated that these enzymes might activate MTZ in cytosol and hydrogenosome, opposing to previous reports of activation occurring exclusively by the hydrogenosomal enzymes pyruvate ferredoxin oxidoreductase and hydrogenase [166]. More recently, [167] it was demonstrated the down-regulation or even 
absent activities of flavin reductase and alcohol dehydrogenase in $T$. vaginalis strains with high levels of MTZ resistance while thioredoxin activity was nearly equal in all strains evaluated, conflicting with previous data that indicated the contribution of these enzymes in resistance $[168,169]$. It is important to emphasize that clinical resistance to MTZ in $T$. vaginalis, also known as aerobic resistance, is fundamentally different from high-level MTZ resistance induced in the laboratory, named anaerobic resistance [143]. The anaerobic resistance is induced in the absence of oxygen and is a consequence of a loss of drug activating enzymatic pathways which are responsible for the reducing of the prodrug MTZ to toxic intermediates [166]. On the other hand, aerobic MTZ resistance seems to be related to elevated intracellular oxygen concentrations in consequence of diminished oxygen scavenging capacity which interferes in the activation of nitroimidazoles [170]. Taking into account the distinct profile observed in $T$. vaginalis isolates the development novel assay methods for detection and the identification of molecular mechanisms of resistance in the parasite are urgent [143].

Considering the possible failures during MTZ treatment either by adverse reactions or by the emergence of resistant clinical isolates, the development of an alternative treatment is recommended. The search for antiparasitic drugs has focused on the identification of active natural products from plant and marine microorganism extracts and compounds with promising anti-T. vaginalis activity (read more in Vieira et al. [171]). The characterization of parasite biochemical and molecular targets such as flavin reductase 1 , pyruvate-ferredoxin oxidoreductase, ferredoxin, and nitroreductases $[172,173]$ is also a potential strategy for new therapeutics. In addition, the development of topic adjuvant treatments and the strategy of repositioning available compounds are included in the pharmacological approaches to expand the trichomoniasis treatment repertoire.

Another research area on new treatment for trichomoniasis and vaginal infections may be focused in to repurpose compounds for use in a new therapeutic application and on revisited drugs, which use has been discontinued for one specific approach but may be effective in another pathogenic context. In the first scenario, Goodhew and Secor [174], screened for 1040 drugs of the US Drug Collection Library for activity against susceptible and resistant $T$. vaginalis isolates. The study shows that among all those drugs no one was as effective as any of the 5-nitroimidazole drugs reinforcing the limitation in developing new therapeutic alternatives for the current therapy. Still of concern is the repurposing of miltefosine, a synthetic lipid analogue used for the treatment of cutaneous metastasis from mammary carcinomas and oral treatment of visceral leishmaniasis has already demonstrated anti- $T$. vaginalis activity in susceptible and resistant isolates $[175,176]$. Other promising candidate is pentamycine, a macrolide antibiotic used for fungal and bacterial vaginitis with high activity against $T$. vaginalis. The effect is prompt and independent of under-lying MTZ resistance [177].
Although effective clinical treatment is widely available, $T$. vaginalis infection remains one of the most common STDs which answers the initial question - no, we are not succeeding in treating trichomoniasis. Reinfection by partners appears to be a major problem, especially when typical symptoms of the infection are absent. According to the most important guidelines, sexual partners should be treated simultaneously. Patients should be advised to abstain from sex at least one week and until they and their partner(s) have completed treatment and patient and partners are asymptomatic.

\section{$\begin{array}{lllll}\text { STRATEGIES TO PREVENT OR ONTROL } & \text { OR CONT }\end{array}$ TRICHOMONIASIS}

Strategies for trichomoniasis protection including sexual behavior, condom usage, and therapy have not contributed to the decrease on disease prevalence, pointing to the need for novel innovative approaches for protection. The $T$. vaginalis infection is curable but is currently far away to be controlled. The treatment with MTZ or TNZ is recommended by the $C D C$; however, cure failures remain problematic due to noncompliance, reinfection and/or lack of treatment of sexual partners, or inaccurate diagnosis since symptoms resemble other STDs. Moreover, increasing numbers of $T$. vaginalis isolates resistant to MTZ argue in favor to improve prevention tools and new treatment alternatives $[3,164]$. Multipurpose prevention technologies are new, all-in-one tools being developed to protect against HIV, other STDs, and unintended pregnancy that, once validated, will certainly contribute to the control of these infections in the future [178].

Vaccine development has been hampered by the lack of long-lasting humoral immunity associated to the absence of good animal models [11]. Only two candidates for trichomonal vaccine have been submitted in clinical trials in the last 50 years, with no success $[179,180]$. Recently, Smith and Garber [181] have tested a FDA approved adjuvant, Alhydrogel, formulated with live, whole cell $T$. vaginalis in the mouse immunized model, with potential applicability. Among the animals tested as in vivo model for T. vaginalis infection: mouse, rat, hamster, guinea pig, rhesus monkey (Macaca mulatta), crab-eating macaque (Macaca irus), stump-tailed macaque (Macaca arctoides), pigtailed macaque (Macaca nemestrina), and squirrel monkey (Saimiri sciureus), the pigtailed macaque is the most promising model since it naturally harbors lactobacilli, has a vaginal $\mathrm{pH}$ of $5.5-8.0$, sustains infection up to 2 weeks and responds to MTZ treatment [182, 183].

A great challenge in trichomoniasis control resides in novel vaccine development associated to effective prevention tools. The goal of a vaccine is hard to be achieved due to intrinsic difficulties related to the multifactorial parasite pathogenesis and new alternatives for the treatment are also urgently needed.

\section{CONCLUDING REMARKS AND PERSPECTIVES}

Despite all accurate studies that have been conducted to understand Trichomonas vaginalis and trichomoniasis, 
there is still a lot of knowledge hidden by this audacious extracellular pathogen. Our answer to the title is no, we are not giving the deserved attention to the most common non-viral STD in the world. Why? Probably because the infection does not directly cause death and health professionals in general are not aware about the serious consequences of the disease. Ideally a collaborative effort of researchers focused in studies on the $T$. vaginalis biology and pathogenesis, the improvement on diagnosis methods and detection of drug resistance in parallel with new treatment and prevention options are required to achieve the goal of reduction of $T$. vaginalis burden in humans.

\section{ACKNOWLEDGMENTS}

Camila B. Menezes thanks Coordenação de Aperfeiçoamento de Pessoal de Nível Superior (CAPES/Brazil) for scholarship and Tiana Tasca thanks Conselho Nacional de Desenvolvimento Científico e Tecnológico (CNPq/Brazil) for researcher

\section{REFERENCES}

1. Secor WE, Meites E, Starr MC, Workowski KA (2014). Neglected parasitic infections in the United States: trichomoniasis. Am J Trop Med Hyg 90(5): 800-804.

2. World Health Organization (2012) Global incidence and prevalence of selected curable sexually transmitted infections - 2008. World Health Organization, Geneva.

3. Schwebke JR, Barrientes FJ (2006). Prevalence of Trichomonas vaginalis isolates with resistance to metronidazole and tinidazole. Antimicrob Agents Chemother 50(12): 4209-4210.

4. Workowski KA, Bolan GA (2015). Sexually transmitted diseases treatment guidelines, 2015. MMWR Recommen Rep 64(Rr-03): 1-137.

5. Carlton JM, Hirt RP, Silva JC, Delcher AL, Schatz M, Zhao $Q$, Wortman JR, Bidwell SL, Alsmark UC, Besteiro S, Sicheritz-Ponten T, Noel CJ, Dacks JB, Foster PG, Simillion C, Van de Peer Y, MirandaSaavedra D, Barton GJ, Westrop GD, Muller S, Dessi D, Fiori PL, Ren Q, Paulsen I, Zhang H, Bastida-Corcuera FD, Simoes-Barbosa A, Brown MT, Hayes RD, Mukherjee $M$, et al. (2007). Draft genome sequence of the sexually transmitted pathogen Trichomonas vaginalis. Science 315(5809): 207-212.

6. Petrin D, Delgaty K, Bhatt R, Garber G (1998). Clinical and microbiological aspects of Trichomonas vaginalis. Clin Microbiol Rev 11(2): 300-317.

7. Lehker MW, Alderete JF (2000). Biology of trichomonosis. Curr Opin Infect Dis 13(1): 37-45.

8. Figueroa-Angulo EE, Rendon-Gandarilla FJ, Puente-Rivera J, CallaChoque JS, Cardenas-Guerra RE, Ortega-Lopez J, Quintas-Granados LI, Alvarez-Sanchez ME, Arroyo R (2012). The effects of environmental factors on the virulence of Trichomonas vaginalis. Microbes Infect 14(15): 1411-1427.

9. Meites E (2013). Trichomoniasis: the "neglected" sexually transmitted disease. Infect Dis Clin North Am 27(4): 755-764.

10. Kusdian G, Gould SB (2014). The biology of Trichomonas vaginalis in the light of urogenital tract infection. Mol Biochem Parasitol 198(2): 92-99.

11. Malla N, Goyal K, Dhanda RS, Yadav M (2014). Immunity in urogenital protozoa. Parasite Immunol 36(9): 400-408. fellowship (grant 307447/2014-6). The support from the Pharmaceutical Sciences Graduation Program (PPGCF/UFRGS) is appreciated by the authors.

\section{CONFLICT OF INTEREST}

The authors declare no conflict of interest.

\section{COPYRIGHT}

(C) 2016 Menezes et al. This is an open-access article released under the terms of the Creative Commons Attribution (CC BY) license, which allows the unrestricted use, distribution, and reproduction in any medium, provided the original author and source are acknowledged.

Please cite this article as: Camila Braz Menezes, Amanda Piccoli Frasson and Tiana Tasca (2016). Trichomoniasis - are we giving the deserved attention to the most common non-viral sexually transmitted disease worldwide? Microbial Cell 3(9): 404-419.

12. Hirt RP, Sherrard J (2015). Trichomonas vaginalis origins, molecular pathobiology and clinical considerations. Curr Opin Infect Dis 28(1): 72-79.

13. Kissinger $P$ (2015). Epidemiology and treatment of trichomoniasis Curr Infect Dis Rep 17(6): 484

14. Bowden FJ, Garnett GP (1999). Why is Trichomonas vaginalis ignored? Sex Transm Infect 75(6): 372-374.

15. Maritz JM, Land KM, Carlton JM, Hirt RP (2014). What is the importance of zoonotic trichomonads for human health? Trends Parasitol 30(7): 333-341.

16. Poole DN, McClelland RS (2013). Global epidemiology of Trichomonas vaginalis. Sex Transm linfect 89(6): 418-422.

17. Pereira-Neves A, Ribeiro KC, Benchimol M (2003). Pseudocysts in trichomonads--new insights. Protist 154(3-4): 313-329.

18. Muller $M$ (1990). Biochemistry of Trichomonas vaginalis. In: HONIGBERG BM, editor Trichomonads parasitic in humans. SpringerVerlag, New York; pp 53-83.

19. Chose O, Sarde C-O, NoËL C, Gerbod D, Jimenez J-C, Brenner C, Capron M, Viscogliosi E, Roseto A (2003). Cell Death in Protists without Mitochondria. Ann N Y Acad Sci 1010(1): 121-125.

20. Benchimol M (2009). Hydrogenosomes under microscopy. Tissue Cell 41(3): 151-168.

21. Hammerschlag MR, Guillen CD (2010). Medical and legal implications of testing for sexually transmitted infections in children. Clin Microbiol Rev 23(3): 493-506

22. Reading R, Rogstad K, Hughes G, Debelle G (2014). Gonorrhoea, chlamydia, syphilis and trichomonas in children under 13 years of age: national surveillance in the UK and Republic of Ireland. Arch Dis Child 99(8): 712-716.

23. Crucitti T, Jespers V, Mulenga C, Khondowe S, Vandepitte J, Buve A (2011). Non-sexual transmission of Trichomonas vaginalis in adolescent girls attending school in Ndola, Zambia. PloS one 6(1): e16310. 
24. Carter JE, Whithaus KC (2008). Neonatal respiratory tract involvement by Trichomonas vaginalis: a case report and review of the literature. Am J Trop Med Hyg. 78(1): 17-19.

25. Duboucher C, Noel C, Durand-Joly I, Gerbod D, Delgado-Viscogliosi P, Jouveshomme S, Leclerc C, Cartolano GL, Dei-Cas E, Capron M Viscogliosi E (2003). Pulmonary coinfection by Trichomonas vaginalis and Pneumocystis sp. as a novel manifestation of AIDS. Hum Patho 34(5): 508-511.

26. Leterrier $M$, Morio $F$, Renard $B T$, Poirier AS, Miegeville $M$, Chambreuil G (2012). Trichomonads in pleural effusion: case report, literature review and utility of PCR for species identification. New Microbiol 35(1): 83-87.

27. Ton Nu PA, Nguyen VQ, Cao NT, Dessi D, Rappelli P, Fiori PL (2015) Prevalence of Trichomonas vaginalis infection in symptomatic and asymptomatic women in Central Vietnam. J Infect Dev Ctries 9(6): 655-660.

28. Campbell L, Woods V, Lloyd T, Elsayed S, Church DL (2008). Evaluation of the OSOM Trichomonas rapid test versus wet preparation examination for detection of Trichomonas vaginalis vaginitis in specimens from women with a low prevalence of infection. J Clin Microbiol 46(10): 3467-3469.

29. Andrea SB, Chapin KC (2011). Comparison of Aptima Trichomonas vaginalis transcription-mediated amplification assay and $B D$ affirm VPIII for detection of T. vaginalis in symptomatic women: performance parameters and epidemiological implications. J Clin Microbiol 49(3): 866-869.

30. Schwebke JR, Hobbs MM, Taylor SN, Sena AC, Catania MG, Weinbaum BS, Johnson AD, Getman DK, Gaydos CA (2011). Molecular testing for Trichomonas vaginalis in women: results from a prospective U.S. clinical trial. J Clin Microbiol 49(12): 4106-4111.

31. Domeika M, Zhurauskaya L, Savicheva A, Frigo N, Sokolovskiy E, Hallen A, Unemo M, Ballard RC (2010). Guidelines for the laboratory diagnosis of trichomoniasis in East European countries. J Eur Acad Dermatol Venereol 24(10): 1125-1134.

32. Allsworth JE, Ratner JA, Peipert JF (2009). Trichomoniasis and other sexually transmitted infections: results from the 2001-2004 National Health and Nutrition Examination Surveys. Sex Transm Dis 36(12): 738-744. doi: 10.1097/OLQ.0b013e3181b38a4b.

33. Forhan SE, Gottlieb SL, Sternberg MR, Xu F, Datta SD, McQuillan GM, Berman SM, Markowitz LE (2009). Prevalence of sexually transmitted infections among female adolescents aged 14 to 19 in the United States. Pediatrics 124(6): 1505-1512.

34. Krashin JW, Koumans EH, Bradshaw-Sydnor AC, Braxton JR, Evan Secor W, Sawyer MK, Markowitz LE (2010). Trichomonas vaginalis prevalence, incidence, risk factors and antibiotic-resistance in an adolescent population. Sex Transm Dis 37(7): 440-444.

35. Chai SJ, Aumakhan B, Barnes M, Jett-Goheen M, Quinn N, Agreda P, Whittle P, Hogan T, Jenkins WD, Rietmeijer CA, Gaydos CA (2010). Internet-based screening for sexually transmitted infections to reach nonclinic populations in the community: risk factors for infection in men. Sex Transm Dis 37(12): 756-763.

36. Gaydos CA, Barnes MR, Quinn N, Jett-Goheen M, Hsieh YH (2013). Trichomonas vaginalis infection in men who submit self-collected penile swabs after internet recruitment. Sex Transm Infect 89(6): 504508.

37. McNicholas C, Peipert JF, Maddipati R, Madden T, Allsworth JE, Secura GM (2013). Sexually transmitted infection prevalence in a population seeking no-cost contraception. Sex Transm Dis 40(7): 546551.

38. Ginocchio CC, Chapin K, Smith JS, Aslanzadeh J, Snook J, Hill CS, Gaydos CA (2012). Prevalence of Trichomonas vaginalis and coinfection with Chlamydia trachomatis and Neisseria gonorrhoeae in the United States as determined by the Aptima Trichomonas vaginalis nucleic acid amplification assay. J Clin Microbiol 50(8): 2601-2608.

39. Meites E, Llata E, Braxton J, Schwebke JR, Bernstein KT, Pathela P Asbel LE, Kerani RP, Mettenbrink CJ, Weinstock HS (2013). Trichomonas vaginalis in selected U.S. sexually transmitted disease clinics: testing, screening, and prevalence. Sex Transm Dis 40(11): 865-869.

40. Swartzendruber A, Sales JM, Brown JL, Diclemente RJ, Rose ES (2014). Correlates of incident Trichomonas vaginalis infections among African American female adolescents. Sex Transm Dis 41(4): 240-245.

41. Kim JK (2013). Epidemiological trends of sexually transmitted infections among women in Cheonan, South Korea, 2006-2012. J Microbiol Biotechnol 23(10): 1484-1490.

42. Madhivanan P, Bartman MT, Pasutti L, Krupp K, Arun A, Reingold AL, Klausner JD (2009). Prevalence of Trichomonas vaginalis infection among young reproductive age women in India: implications for treatment and prevention. Sex Health 6(4): 339-344.

43. Ryder N, Woods H, McKay K, Giddings N, Lenton JA, Little C Jeoffreys N, McNulty AM (2012). Trichomonas vaginalis prevalence increases with remoteness in rural and remote New South Wales, Australia. Sex Transm Dis 39(12): 938-941.

44. Bygott JM, Robson JM (2013). The rarity of Trichomonas vaginalis in urban Australia. Sex Transm Infect 89(6): 509-513.

45. Faber MT, Nielsen A, Nygard M, Sparen P, Tryggvadottir L, Hansen BT, Liaw KL, Kjaer SK (2011). Genital chlamydia, genital herpes, Trichomonas vaginalis and gonorrhea prevalence, and risk factors among nearly 70,000 randomly selected women in 4 Nordic countries. Sex Transmitted Dis 38(8): 727-734

46. Naidoo S, Wand $H$ (2013). Prevalence and incidence of Trichomonas vaginalis infections in women participating in a clinical trial in Durban, South Africa. Sex Transm Infect 89(6): 519-522.

47. Salomon MC, Martinez N, Delgado D, Gonzalez Arra C, Bittar V, Gonzalez N (2011). Trichomonas vaginalis prevalence in sex workers. Medicina 71(5): 429-431.

48. Neira O. P, Correa LL. A, Muñoz S. N, Tardío O. MT, Carabelli F. M (2005). Frecuencia de infección por Trichomonas vaginalis en atención primaria de salud. Rev Chil Obstet Ginecol 70:147-151.

49. Leon SR, Konda KA, Bernstein KT, Pajuelo JB, Rosasco AM, Caceres CF, Coates TJ, Klausner JD (2009). Trichomonas vaginalis infection and associated risk factors in a socially-marginalized female population in coastal Peru. Infecti Diseases Obstet Gynecol 2009:752437.

50. Rafael V.Michel FPB, Renata C. M. Wiltuschnig, Francine G. Neves, Juliana Ribeiro, Renata C. Vieiro, Patrícia B. Vieira, Gabriela R. Bohns, Tiana Tasca, Geraldo A. De Carli (2006). Prevalência da tricomonose em mulheres residentes na Vila dos Papeleiros em Porto Alegre, RS. RBAC 38(2): 127-130.

51. Luppi CG, de Oliveira RL, Veras MA, Lippman SA, Jones $H$, de Jesus $\mathrm{CH}$, Pinho AA, Ribeiro MC, Caiaffa-Filho $\mathrm{H}$ (2011). Early diagnosis and correlations of sexually transmitted infections among women in primary care health services. Rev Bras Epidemiol 14(3): 467-477.

52. Grama DF, Casarotti Lda S, Morato MG, Silva LS, Mendonca DF, Limongi JE, Viana Jda C, Cury MC (2013). Prevalence of Trichomonas vaginalis and risk factors in women treated at public health units in Brazil: a transversal study. Trans R Soc Trop Med Hyg 107(9): 584-591.

53. Rocha DA, Filho RA, Marino JM, dos Santos CM (2014). "Hidden" sexually transmitted infections among women in primary care health services, Amazonas, Brazil. Int J STD AIDS 25(12): 878-886

54. Ministério da Saúde. Secretaria de Vigilância em Saúde. Programa Nacional de DST e Aids. Prevalências e freqüências relativas de 
Doenças Sexualmente Transmissíveis (DST) em populações selecionadas de seis capitais brasileiras ,2005. Ministério da Saúde, Secretaria de Vigilância em Saúde, Programa Nacional de DST e Aids.

55. Fichorova RN (2009). Impact of T. vaginalis infection on innate immune responses and reproductive outcome. J Reprod Immunol 83(1-2): 185-189.

56. Owusu-Edusei K, Jr., Chesson HW, Gift TL, Tao G, Mahajan R, Ocfemia MC, Kent CK (2013). The estimated direct medical cost of selected sexually transmitted infections in the United States, 2008. Sex Transm Dis 40(3): 197-201.

57. Chesson HW, Blandford JM, Pinkerton SD (2004). Estimates of the annual number and cost of new HIV infections among women attributable to trichomoniasis in the United States. Sex Transm Dis 31(9): 547-551.

58. Zhang ZF, Begg CB (1994). Is Trichomonas vaginalis a cause of cervical neoplasia? Results from a combined analysis of 24 studies. Int J Epidemiol 23(4): 682-690.

59. Sutcliffe S, Neace C, Magnuson NS, Reeves R, Alderete JF (2012). Trichomonosis, a common curable STI, and prostate carcinogenesis - a proposed molecular mechanism. PLoS Pathog 8(8): e1002801.

60. Viikki M, Pukkala E, Nieminen P, Hakama M (2000). Gynaecological infections as risk determinants of subsequent cervical neoplasia. Acta Oncol 39(1): 71-75.

61. Cotch MF, Pastorek JG, 2nd, Nugent RP, Hillier SL, Gibbs RS, Martin DH, Eschenbach DA, Edelman R, Carey JC, Regan JA, Krohn MA, Klebanoff MA, Rao AV, Rhoads GG (1997). Trichomonas vaginalis associated with low birth weight and preterm delivery. The vaginal infections and prematurity study group. Sex Transm Dis 24(6): 353360

62. Cotch MF, Pastorek JG, 2nd, Nugent RP, Yerg DE, Martin DH, Eschenbach DA (1991). Demographic and behavioral predictors of Trichomonas vaginalis infection among pregnant women. The Vaginal Infections and Prematurity Study Group. Obstet Gynecol 78(6): 10871092.

63. Klebanoff MA, Carey JC, Hauth JC, Hillier SL, Nugent RP, Thom EA, Ernest JM, Heine RP, Wapner RJ, Trout W, Moawad A, Leveno KJ, Miodovnik M, Sibai BM, Van Dorsten JP, Dombrowski MP, O'Sullivan MJ, Varner M, Langer O, McNellis D, Roberts JM (2001). Failure of metronidazole to prevent preterm delivery among pregnant women with asymptomatic Trichomonas vaginalis infection. N Engl J Med 345(7): 487-493

64. Silver BJ, Guy RJ, Kaldor JM, Jamil MS, Rumbold AR (2014). Trichomonas vaginalis as a cause of perinatal morbidity: a systematic review and meta-analysis. Sex Transm Dis 41(6): 369-376.

65. Grodstein F, Goldman MB, Cramer DW (1993). Relation of tubal infertility to history of sexually transmitted diseases. Epidemiol Rev 137(5): 577-584

66. Gimenes F, Souza RP, Bento JC, Teixeira JJ, Maria-Engler SS, Bonini MG, Consolaro ME (2014). Male infertility: a public health issue caused by sexually transmitted pathogens. Nat Rev Urol 11(12): 672 687

67. McClelland RS, Sangare L, Hassan WM, Lavreys L, Mandaliya K, Kiarie J, Ndinya-Achola J, Jaoko W, Baeten JM (2007). Infection with Trichomonas vaginalis increases the risk of HIV-1 acquisition. J Infect Dis 195(5): 698-702.

68. Quinlivan EB, Patel SN, Grodensky CA, Golin CE, Tien HC, Hobbs MM (2012). Modeling the impact of Trichomonas vaginalis infection on HIV transmission in HIV-infected individuals in medical care. Sex Transm Dis 39(9): 671-677.
70. Swygard H, Seña AC, Hobbs MM, Cohen MS (2004). Trichomoniasis: clinical manifestations, diagnosis and management. Sex Transm Infect 80(2): 91-95.

71. Sutton M, Sternberg M, Koumans EH, McQuillan G, Berman S, Markowitz $L$ (2007). The prevalence of Trichomonas vaginalis infection among reproductive-age women in the United States, 2001-2004. Clinical Infectious Dis 45(10): 1319-1326.

72. Muzny CA, Schwebke JR (2013). The clinical spectrum of Trichomonas vaginalis infection and challenges to management. Sex Transm Infect 89(6): 423-425.

73. Schwebke JR, Burgess D (2004). Trichomoniasis. Clin Microbiol Rev 17(4): 794-803

74. Lazenby GB, Soper DE, Nolte FS (2013). Correlation of leukorrhea and Trichomonas vaginalis infection. J Clin Microbiol 51(7): 2323-2327.

75. Cherpes TL, Wiesenfeld HC, Melan MA, Kant JA, Cosentino LA, Meyn LA, Hillier SL (2006). The associations between pelvic inflammatory disease, Trichomonas vaginalis infection, and positive Herpes simplex virus type 2 serology. Sex Transm Dis 33(12): 747-752.

76. Stark JR, Judson G, Alderete JF, Mundodi V, Kucknoor AS Giovannucci EL, Platz EA, Sutcliffe S, Fall K, Kurth T, Ma J, Stampfer MJ, Mucci LA (2009). Prospective study of Trichomonas vaginalis infection and prostate cancer incidence and mortality: Physicians' Health Study. J Natl Cancer Inst 101(20): 1406-1411.

77. Sutcliffe S, Giovannucci E, Alderete JF, Chang TH, Gaydos CA Zenilman JM, De Marzo AM, Willett WC, Platz EA (2006). Plasma antibodies against Trichomonas vaginalis and subsequent risk of prostate cancer. Cancer Epidemiol Biomarkers Prev 15(5): 939-945.

78. Sutcliffe S, Alderete JF, Till C, Goodman PJ, Hsing AW, Zenilman JM, De Marzo AM, Platz EA (2009). Trichomonosis and subsequent risk of prostate cancer in the Prostate Cancer Prevention Trial. Int J Cancer 124(9): 2082-2087.

79. Caini S, Gandini S, Dudas M, Bremer V, Severi E, Gherasim A (2014). Sexually transmitted infections and prostate cancer risk: a systematic review and meta-analysis. Cancer Epidemiol 38(4): 329-338.

80. Sorvillo F, Smith L, Kerndt P, Ash L (2001). Trichomonas vaginalis, HIV, and African-Americans. Emerg Infect Dis 7(6): 927-932.

81. Van Der Pol B, Kwok C, Pierre-Louis B, Rinaldi A, Salata RA, Chen PL, van de Wijgert J, Mmiro F, Mugerwa R, Chipato T, Morrison CS (2008). Trichomonas vaginalis infection and human immunodeficiency virus acquisition in African women. J Infect Dis 197(4): 548-554.

82. Kissinger $P$, Adamski A (2013). Trichomoniasis and HIV interactions: a review. Sex Transm Infect 89(6): 426-433.

83. Lushbaugh WB, Turner AC, Gentry GA, Klykken PC (1989). Characterization of a secreted cytoactive factor from Trichomonas vaginalis. Am J Trop Med Hyg 41(1): 18-28.

84. Garber GE, Lemchuk-Favel LT (1990). Association of production of cell-detaching factor with the clinical presentation of Trichomonas vaginalis. J Clin Microbiol 28(11): 2415-2417.

85. Hernandez HM, Marcet R, Sarracent J (2014). Biological roles of cysteine proteinases in the pathogenesis of Trichomonas vaginalis. Parasite 21:54

86. Arroyo R, Alderete JF (1989). Trichomonas vaginalis surface proteinase activity is necessary for parasite adherence to epithelial cells. Infect Immun 57(10): 2991-2997.

87. Ryan CM, de Miguel N, Johnson PJ (2011). Trichomonas vaginalis: current understanding of host-parasite interactions. Essays in Biochemistry 51(161-175. 
88. Sommer U, Costello CE, Hayes GR, Beach DH, Gilbert RO, Lucas JJ, Singh BN (2005). Identification of Trichomonas vaginalis cysteine proteases that induce apoptosis in human vaginal epithelial cells. J Biol Chem 280(25): 23853-23860.

89. Arroyo R, Cardenas-Guerra RE, Figueroa-Angulo EE, Puente-Rivera J, Zamudio-Prieto O, Ortega-Lopez J (2015). Trichomonas vaginalis Cysteine Proteinases: Iron Response in Gene Expression and Proteolytic Activity. Biomed Res Int 2015:946787.

90. Lehker MW, Chang TH, Dailey DC, Alderete JF (1990). Specific erythrocyte binding is an additional nutrient acquisition system for Trichomonas vaginalis. J Exp Med 171(6): 2165-2170

91. Fiori PL, Rappelli P, Addis MF (1999). The flagellated parasite Trichomonas vaginalis: new insights into cytopathogenicity mechanisms. Microbes Infect 1(2): 149-156.

92. Arroyo R, Alderete JF (1995). Two Trichomonas vaginalis surface proteinases bind to host epithelial cells and are related to levels of cytoadherence and cytotoxicity. Arch Med Res 26(3): 279-285.

93. Lubick KJ, Burgess DE (2004). Purification and analysis of a phospholipase A2-like lytic factor of Trichomonas vaginalis. Infect Immun 72(3): 1284-1290.

94. Mendoza-Lopez MR, Becerril-Garcia C, Fattel-Facenda LV, AvilaGonzalez L, Ruiz-Tachiquin ME, Ortega-Lopez J, Arroyo R (2000). CP30, a cysteine proteinase involved in Trichomonas vaginalis cytoadherence. Infect Immun 68(9): 4907-4912.

95. Dailey DC, Chang TH, Alderete JF (1990). Characterization of Trichomonas vaginalis haemolysis. Parasitology 101 Pt 2:171-175.

96. Fiori PL, Rappelli P, Addis MF, Sechi A, Cappuccinelli P (1996). Trichomonas vaginalis haemolysis: $\mathrm{pH}$ regulates a contactindependent mechanism based on pore-forming proteins. Microb Pathog 20(2): 109-118.

97. Ojcius DM, Young JD (1991). Cytolytic pore-forming proteins and peptides: is there a common structural motif? Trends Biochem Sci 16(6): 225-229.

98. Hecht O, Van Nuland NA, Schleinkofer K, Dingley AJ, Bruhn H, Leippe M, Grotzinger J (2004). Solution structure of the pore-forming protein of Entamoeba histolytica. J Biol Chem 279(17): 17834-17841.

99. Herbst R, Marciano-Cabral F, Leippe M (2004). Antimicrobial and pore-forming peptides of free-living and potentially highly pathogenic Naegleria fowleri are released from the same precursor molecule. J Biol Chem 279(25): 25955-25958.

100. Zhai Y, Saier MH, Jr. (2000). The amoebapore superfamily. Biochimica et biophysica acta 1469(2): 87-99.

101. Coceres VM, Alonso AM, Nievas YR, Midlej V, Frontera L, Benchimol M, Johnson PJ, de Miguel N (2015). The C-terminal tail of tetraspanin proteins regulates their intracellular distribution in the parasite Trichomonas vaginalis. Cell Microbiol 17(8): 1217-1229.

102. Twu O, de Miguel N, Lustig G, Stevens GC, Vashisht AA, Wohlschlegel JA, Johnson PJ (2013). Trichomonas vaginalis exosomes deliver cargo to host cells and mediate hostratioparasite interactions. PLoS pathog 9(7): e1003482.

103. Twu O, Dessi D, Vu A, Mercer F, Stevens GC, de Miguel N, Rappelli P, Cocco AR, Clubb RT, Fiori PL, Johnson PJ (2014). Trichomonas vaginalis homolog of macrophage migration inhibitory factor induces prostate cell growth, invasiveness, and inflammatory responses. PNAS 111(22): 8179-8184.

104. Gould SB, Woehle C, Kusdian G, Landan G, Tachezy J, Zimorski V, Martin WF (2013). Deep sequencing of Trichomonas vaginalis during the early infection of vaginal epithelial cells and amoeboid transition. Int J Parasitol 43(9): 707-719.
105. Alderete JF, Benchimol M, Lehker MW, Crouch ML (2002). The complex fibronectin--Trichomonas vaginalis interactions and Trichomonosis. Parasitol Int 51(3): 285-292.

106. Lehker MW, Sweeney D (1999). Trichomonad invasion of the mucous layer requires adhesins, mucinases, and motility. Sex Transm Infect 75(4): 231-238.

107. Okumura CY, Baum LG, Johnson PJ (2008). Galectin-1 on cervical epithelial cells is a receptor for the sexually transmitted human parasite Trichomonas vaginalis. Cell Microbiol 10(10): 2078-2090.

108. Fichorova RN, Yamamoto HS, Fashemi T, Foley E, Ryan S, Beatty N, Dawood H, Hayes GR, St-Pierre G, Sato S, Singh BN (2015). Trichomonas vaginalis lipophosphoglycan exploits binding to Galectin1 and -3 to modulate epithelial immunity. J Biol Chem

109. Bastida-Corcuera FD, Singh BN, Gray GC, Stamper PD, Davuluri M, Schlangen K, Corbeil RR, Corbeil LB (2013). Antibodies to Trichomonas vaginalis surface glycolipid. Sex Transm Infec 89(6): 467-472.

110. Fichorova RN, Trifonova RT, Gilbert RO, Costello CE, Hayes GR, Lucas JJ, Singh BN (2006). Trichomonas vaginalis lipophosphoglycan triggers a selective upregulation of cytokines by human female reproductive tract epithelial cells. Infect Immun 74(10): 5773-5779.

111. Shiflett AM, Johnson PJ (2010). Mitochondrion-related organelles in eukaryotic protists. Annu Rev Microbiol 64(409-429.

112. Engbring JA, Alderete JF (1998). Characterization of Trichomonas vaginalis AP33 adhesin and cell surface interactive domains. Microbiology 144 ( Pt 11):3011-3018.

113. Garcia AF, Alderete J (2007). Characterization of the Trichomonas vaginalis surface-associated AP65 and binding domain interacting with trichomonads and host cells. BMC microbiology 7:116.

114. Alderete JF, Millsap KW, Lehker MW, Benchimol M (2001). Enzymes on microbial pathogens and Trichomonas vaginalis: molecular mimicry and functional diversity. Cell Microbiol 3(6): 359370.

115. Hirt RP, Noel CJ, Sicheritz-Ponten T, Tachezy J, Fiori PL (2007). Trichomonas vaginalis surface proteins: a view from the genome. Trends Parasitol 23(11): 540-547.

116. Moreno-Brito V, Yanez-Gomez C, Meza-Cervantez P, AvilaGonzalez L, Rodriguez MA, Ortega-Lopez J, Gonzalez-Robles A, Arroyo $\mathrm{R}$ (2005). A Trichomonas vaginalis $120 \mathrm{kDa}$ protein with identity to hydrogenosome pyruvate:ferredoxin oxidoreductase is a surface adhesin induced by iron. Cell Microbiol 7(2): 245-258.

117. Arroyo R, Engbring J, Alderete JF (1992). Molecular basis of host epithelial cell recognition by Trichomonas vaginalis. Mol Microbiol 6(7): 853-862.

118. Addis MF, Rappelli P, Fiori PL (2000). Host and tissue specificity of Trichomonas vaginalis is not mediated by its known adhesion proteins. Infect Immun 68(7): 4358-4360.

119. Ardalan S, Lee BC, Garber GE (2009). Trichomonas vaginalis: the adhesins AP51 and AP65 bind heme and hemoglobin. Exp Parasitol 121(4): 300-306.

120. Lehker MW, Arroyo R, Alderete JF (1991). The regulation by iron of the synthesis of adhesins and cytoadherence levels in the protozoan Trichomonas vaginalis. J Exp Med 174(2): 311-318.

121. Garcia AF, Chang TH, Benchimol M, Klumpp DJ, Lehker MW, Alderete JF (2003). Iron and contact with host cells induce expression of adhesins on surface of Trichomonas vaginalis. Mol Microbiol 47(5): 1207-1224.

122. Noel CJ, Diaz N, Sicheritz-Ponten T, Safarikova L, Tachezy J, Tang $\mathrm{P}$, Fiori PL, Hirt RP (2010). Trichomonas vaginalis vast BspA-like gene 
family: evidence for functional diversity from structural organisation and transcriptomics. BMC genomics 11:99.

123. Pereira-Neves A, Benchimol M (2007). Phagocytosis by Trichomonas vaginalis: new insights. Biol Cell 99(2): 87-101.

124. Rendon-Maldonado JG, Espinosa-Cantellano M, Gonzalez-Robles A, Martinez-Palomo A (1998). Trichomonas vaginalis: in vitro phagocytosis of lactobacilli, vaginal epithelial cells, leukocytes, and erythrocytes. Exp Parasitol 89(2): 241-250.

125. Hernandez-Gutierrez R, Avila-Gonzalez L, Ortega-Lopez J, CruzTalonia F, Gomez-Gutierrez G, Arroyo R (2004). Trichomonas vaginalis: characterization of a $39-k D a$ cysteine proteinase found in patient vaginal secretions. Exp Parasitol 107(3-4): 125-135.

126. Alderete JF, Provenzano D, Lehker MW (1995). Iron mediates Trichomonas vaginalis resistance to complement lysis. Microb Pathog 19(2): 93-103.

127. Ryu JS, Kang JH, Jung SY, Shin MH, Kim JM, Park H, Min DY (2004). Production of interleukin-8 by human neutrophils stimulated with Trichomonas vaginalis. Infect Imm 72(3): 1326-1332.

128. Frasson A, Carli G, Bonan C, Tasca T (2012). Involvement of purinergic signaling on nitric oxide production by neutrophils stimulated with Trichomonas vaginalis. Purinergic Signal 8(1): 1-9.

129. Yadav M, Gupta I, Malla N (2005). Kinetics of immunoglobulin G, $M, A$ and IgG subclass responses in experimental intravaginal trichomoniasis: prominence of $\operatorname{lgG} 1$ response. Parasite Immunol 27(12): 461-467.

130. Imam NF, Eassa AH, Shoeib EY, Abo-Raia GY (2007). Antibody isotypes in urethral swabs of symptomatic and asymptomatic men infected with Trichomonas vaginalis. J Egypt Soc Parasitol 37(3): 977 988

131. Cudmore SL, Delgaty KL, Hayward-McClelland SF, Petrin DP, Garber GE (2004). Treatment of infections caused by metronidazoleresistant Trichomonas vaginalis. Clin Microbiol Rev 17(4): 783-793.

132. Rappelli P, Carta F, Delogu G, Addis MF, Dessi D, Cappuccinelli P, Fiori PL (2001). Mycoplasma hominis and Trichomonas vaginalis symbiosis: multiplicity of infection and transmissibility of $\mathrm{M}$. hominis to human cells. Arch Microbiol 175(1): 70-74.

133. Butler SE, Augostini P, Secor WE (2010). Mycoplasma hominis infection of Trichomonas vaginalis is not associated with metronidazole-resistant trichomoniasis in clinical isolates from the United States. Parasitol Res 107(4): 1023-1027.

134. Becker DL, Santos O, Frasson AP, Rigo GV, Macedo AJ, Tasca T (2015). High rates of double-stranded RNA viruses and Mycoplasma hominis in Trichomonas vaginalis clinical isolates in South Brazil. Infect Genet Evol 34:181-187.

135. Xiao JC, Xie LF, Fang SL, Gao MY, Zhu Y, Song LY, Zhong HM, Lun ZR (2006). Symbiosis of Mycoplasma hominis in Trichomonas vaginalis may link metronidazole resistance in vitro. Parasitol Res 100(1): 123130.

136. Vancini RG, Pereira-Neves A, Borojevic R, Benchimol M (2008). Trichomonas vaginalis harboring Mycoplasma hominis increases cytopathogenicity in vitro. Eur J Clin Microbiol Infect Dis 27(4): 259267.

137. Fiori PL, Diaz N, Cocco AR, Rappelli P, Dessi D (2013). Association of Trichomonas vaginalis with its symbiont Mycoplasma hominis synergistically upregulates the in vitro proinflammatory response of human monocytes. Sex Transm Infect 89(6): 449-454.

138. Goodman RP, Freret TS, Kula T, Geller AM, Talkington MW, TangFernandez V, Suciu O, Demidenko AA, Ghabrial SA, Beach DH, Singh $B N$, Fichorova RN, Nibert ML (2011). Clinical isolates of Trichomonas vaginalis concurrently infected by strains of up to four Trichomonasvirus species (Family Totiviridae). J Virol 85(9): 4258-4270.

139. Kim JW, Chung PR, Hwang MK, Choi EY (2007). Double-stranded RNA virus in Korean isolate $\mathrm{IH}-2$ of Trichomonas vaginalis. Korean J Parasitol 45(2): 87-94.

140. Weber B, Mapeka TM, Maahlo MA, Hoosen AA (2003). Double stranded RNA virus in South African Trichomonas vaginalis isolates. J Clin Pathol 56(7): 542-543.

141. Khoshnan A, Alderete JF (1994). Trichomonas vaginalis with a double-stranded RNA virus has upregulated levels of phenotypically variable immunogen mRNA. J Virology 68(6): 4035-4038.

142. Fichorova RN, Lee $Y$, Yamamoto HS, Takagi $Y$, Hayes GR, Goodman RP, Chepa-Lotrea X, Buck OR, Murray R, Kula T, Beach DH, Singh BN, Nibert ML (2012). Endobiont viruses sensed by the human host - beyond conventional antiparasitic therapy. PloS one $7(11)$ : e48418.

143. Conrad MD, Bradic M, Warring SD, Gorman AW, Carlton JM (2013). Getting trichy: tools and approaches to interrogating Trichomonas vaginalis in a post-genome world. Trends Parasitol 29(1): 17-25.

144. Huang KY, Chien KY, Lin YC, Hsu WM, Fong IK, Huang PJ, Yueh YM, Gan RR, Tang P (2009). A proteome reference map of Trichomonas vaginalis. Parasitol Res 104(4): 927-933.

145. Huang KY, Chen YY, Fang YK, Cheng WH, Cheng CC, Chen YC, Wu $T E$, Ku FM, Chen SC, Lin R, Tang $P$ (2014). Adaptive responses to glucose restriction enhance cell survival, antioxidant capability, and autophagy of the protozoan parasite Trichomonas vaginalis. Biochim Biophys Acta 1840(1): 53-64.

146. Cheng WH, Huang KY, Huang PJ, Hsu JH, Fang YK, Chiu CH, Tang P (2015). Nitric oxide maintains cell survival of Trichomonas vaginalis upon iron depletion. Parasit Vectors 8:393.

147. Horvathova L, Safarikova L, Basler M, Hrdy I, Campo NB, Shin JW, Huang KY, Huang PJ, Lin R, Tang P, Tachezy J (2012). Transcriptomic identification of iron-regulated and iron-independent gene copies within the heavily duplicated Trichomonas vaginalis genome. Genome Biol Evol 4(10): 1017-1029.

148. Fang YK, Huang KY, Huang PJ, Lin R, Chao M, Tang P (2015). Geneexpression analysis of cold-stress response in the sexually transmitted protist Trichomonas vaginalis. J Microbiol Immunol Infect 48(6): 662675.

149. Huang KY, Huang PJ, Ku FM, Lin R, Alderete JF, Tang P (2012). Comparative transcriptomic and proteomic analyses of Trichomonas vaginalis following adherence to fibronectin. Infect Immun 80(11): 3900-3911.

150. Yeh YM, Huang KY, Richie Gan RC, Huang HD, Wang TC, Tang $P$ (2013). Phosphoproteome profiling of the sexually transmitted pathogen Trichomonas vaginalis. J Microbiol Immunol Infect. 46(5): 366-373.

151. Huang KY, Ku FM, Cheng WH, Lee CC, Huang PJ, Chu LJ, Cheng CC, Fang YK, Wu HH, Tang $P$ (2015). Novel insights into the molecular events linking to cell death induced by tetracycline in the amitochondriate protozoan Trichomonas vaginalis. Antimicrob Agents Chemother 59(11): 6891-6903.

152. Forna F, Gulmezoglu AM (2003). Interventions for treating trichomoniasis in women. Cochrane Database Syst Rev (2): Cd000218.

153. Sherrard J, Ison C, Moody J, Wainwright E, Wilson J, Sullivan A (2014). United Kingdom National Guideline on the Management of Trichomonas vaginalis 2014. Int J STD AIDS 25(8): 541-549. 
154. Spence MR, Harwell TS, Davies MC, Smith JL (1997). The minimum single oral metronidazole dose for treating trichomoniasis: a randomized, blinded study. Obstet Gynecol 89(5 Pt 1): 699-703.

155. Kissinger $P$, Mena L, Levison J, Clark RA, Gatski M, Henderson $H$, Schmidt N, Rosenthal SL, Myers L, Martin DH (2010). A randomized treatment trial: single versus 7-day dose of metronidazole for the treatment of Trichomonas vaginalis among HIV-infected women. J Acquir Immune Defic Syndr 55(5): 565-571.

156. Tidwell $B H$, Lushbaugh WB, Laughlin MD, Cleary JD, Finley RW (1994). A double-blind placebo-controlled trial of single-dose intravaginal versus single-dose oral metronidazole in the treatment of trichomonal vaginitis. J Infect Dis 170(1): 242-246.

157. Schwebke JR, Desmond RA (2011). Tinidazole vs metronidazole for the treatment of bacterial vaginosis. Am J Obstet Gynecol 204(3): 211.e211-216.

158. Pearlman MD, Yashar C, Ernst S, Solomon W (1996). An incremental dosing protocol for women with severe vaginal trichomoniasis and adverse reaction to metronidazole. Am J Obstet Gynecol 174(3): 934-936.

159. Burtin P, Taddio A, Ariburnu O, Einarson TR, Koren G (1995) Safety of metronidazole in pregnancy: a meta-analysis. Am J Obstet Gynecol 172(2 Pt 1): 525-529.

160. Piper JM, Mitchel EF, Ray WA (1993). Prenatal use of metronidazole and birth defects: no association. Obstet Gynecol 82(3): 348-352.

161. Sheehy O, Santos F, Ferreira E, Berard A (2015). The use of metronidazole during pregnancy: a review of evidence. Curr Drug Saf 10(2): 170-179.

162. Sherrard J, Ison C, Moody J, Wainwright E, Wilson J, Sullivan A (2014). United Kingdom National Guideline on the Management of Trichomonas vaginalis 2014. Int J STD AIDS 25(8): 541-549.

163. Das S, Huengsberg M, Shahmanesh M (2005). Treatment failure of vaginal trichomoniasis in clinical practice. Int J STD AIDS 16(4): 284 286

164. Kirkcaldy RD, Augostini $P$, Asbel LE, Bernstein KT, Kerani RP Mettenbrink CJ, Pathela P, Schwebke JR, Secor WE, Workowski KA, Davis D, Braxton J, Weinstock HS (2012). Trichomonas vaginalis antimicrobial drug resistance in 6 US cities, STD Surveillance Network, 2009-2010. Emerg Infect Dis 18(6): 939-943.

165. Pal D, Banerjee S, Cui J, Schwartz A, Ghosh SK, Samuelson J (2009). Giardia, Entamoeba, and Trichomonas enzymes activate metronidazole (nitroreductases) and inactivate metronidazole (nitroimidazole reductases). Antimicrob Agents Chemother 53(2): 458-464.

166. Kulda J (1999). Trichomonads, hydrogenosomes and drug resistance. Int J Parasitol 29(2): 199-212.

167. Leitsch D, Drinic M, Kolarich D, Duchene M (2012). Downregulation of flavin reductase and alcohol dehydrogenase-1 (ADH1) in metronidazole-resistant isolates of Trichomonas vaginalis. Mol Biochem Parasitol 183(2): 177-183.

168. Leitsch D, Kolarich D, Binder M, Stadlmann J, Altmann F, Duchene $M$ (2009). Trichomonas vaginalis: metronidazole and other nitroimidazole drugs are reduced by the flavin enzyme thioredoxin reductase and disrupt the cellular redox system. Implications for nitroimidazole toxicity and resistance. Mol Microbiol 72(2): 518-536.
169. Leitsch D, Kolarich D, Duchene $M$ (2010). The flavin inhibitor diphenyleneiodonium renders Trichomonas vaginalis resistant to metronidazole, inhibits thioredoxin reductase and flavin reductase, and shuts off hydrogenosomal enzymatic pathways. Mol Biochem Parasitol 171(1): 17-24

170. Yarlett N, Yarlett NC, Lloyd D (1986). Metronidazole-resistant clinical isolates of Trichomonas vaginalis have lowered oxygen affinities. Mol Biochem Parasitol 19(2): 111-116.

171. Vieira PB, Giordani RB, Macedo AJ, Tasca T (2015). Natural and synthetic compound anti-Trichomonas vaginalis: an update review. Parasitol Res 114(4): 1249-1261.

172. Leitsch D, Janssen BD, Kolarich D, Johnson PJ, Duchene M (2014). Trichomonas vaginalis flavin reductase 1 and its role in metronidazole resistance. Mol Microbiol 91(1): 198-208.

173. Paulish-Miller TE, Augostini P, Schuyler JA, Smith WL, Mordecha E, Adelson ME, Gygax SE, Secor WE, Hilbert DW (2014). Trichomonas vaginalis metronidazole resistance is associated with single nucleotide polymorphisms in the nitroreductase genes ntr4Tv and ntr6Tv. Antimicrob Agents Chemother 58(5): 2938-2943.

174. Goodhew EB, Secor WE (2013). Drug library screening against metronidazole-sensitive and metronidazole-resistant Trichomonas vaginalis isolates. Sex Transm Infect 89(6): 479-484.

175. Blaha C, Duchêne M, Aspöck H, Walochnik J (2006). In vitro activity of hexadecylphosph ocholine (miltefosine) against metronidazole-resistant and -susceptible strains of Trichomonas vaginalis. J Antimicrob Chemother 57(2): 273-278.

176. Rocha DA, de Andrade Rosa I, de Souza W, Benchimol M (2014). Evaluation of the effect of miltefosine on Trichomonas vaginalis. Parasitol Res 113(3): 1041-1047.

177. Kranzler M, Syrowatka M, Leitsch D, Winnips C, Walochnik J (2015). Pentamycin shows high efficacy against Trichomonas vaginalis. Int J Antimicrob Agents 45(4): 434-437.

178. Fernandez-Romero JA, Deal C, Herold BC, Schiller J, Patton D, Zydowsky T, Romano J, Petro CD, Narasimhan M (2015). Multipurpose prevention technologies: the future of HIV and STI protection. Trends Microbiol 23(7): 429-436

179. Aburel E, Zervos G, Titea V, Pana S (1963). Immunological and therapeutic investiations in vaginal trichomoniasis. Rum Med Rev 7:13-19.

180. Alderete JF (1988). Does lactobacillus vaccine for trichomoniasis, Solco Trichovac, induce antibody reactive with Trichomonas vaginalis? Genitourin Med 64(2): 118-123.

181. Smith J, Garber GE (2014). Current status and prospects for development of a vaccine against Trichomonas vaginalis infections. Vaccine 32(14): 1588-1594.

182. Kulda J (1990). Employment of experimental animals in studies of Trichomonas vaginalis infection. In: Honigberg BM, editor Trichomonads parasitic in humans. Springer-Verlag, New York; pp 112-154.

183. Patton DL, Sweeney YT, Agnew KJ, Balkus JE, Rabe LK, Hillier SL (2006). Development of a nonhuman primate model for Trichomonas vaginalis infection. Sex Transmitted Dis 33(12): 743-746. 